\title{
AOR
}

Selected Papers of \#AolR2021:

The 22nd Annual Conference of the Association of Internet Researchers Virtual Event / 13-16 Oct 2021

\section{WHEN DEATH DEPENDS ON NETWORKED INFORMATION}

\author{
Jacqueline Wernimont \\ Dartmouth
}

Tamara Kneese

University of San Fransisco

Tonia Sutherland

University of Hawaii

Marika Cifor

University of Washington

\section{Land acknowledgements:}

Marika Cifor: Seattle and the University of Washington stand on the unceded land of the Coast Salish peoples, land which touches the shared waters of all tribes and bands within the Duwamish, Suquamish, Tulalip and Muckleshoot nations. We acknowledge the ancestral homelands of those who walked here before us and those who still walk here.

Tamara Kneese: I acknowledge that the University of San Francisco is located on the unceded ancestral homeland of the Ramaytush Ohlone peoples who are the original inhabitants of the San Francisco Peninsula. I recognize that I benefit from living and working on their traditional homeland. I acknowledge the painful history of genocide and forced removal from this territory, and I celebrate the public presence of Ohlone descendants who are working today to preserve and nourish their Indigenous identity.

Tonia Sutherland: joins us from Honolulu, Hawai' i, where she is a guest and uninvited visitor on the unceded 'aina (land) of the Kānaka Maoli, or Native Hawaiian, people. Tonia also calls upon the grace and guidance of her Afro-Caribbean ancestors from Trinidad and Tobago, St. Vincent and the Grenadines, and St. Lucia as she does this work.

Jacque Wernimont: Dartmouth was founded in an act of land and community theft and under the auspices of the colonial project of Britain. Dartmouth College was founded to educate Native American youth in both Christian and colonial, Western ideology. As staff and residents here, we occupy the lands of the Abenaki and other Algonquin peoples who continue to live and work

Suggested Citation (APA): Wernimont, J., Kneese, T., Sutherland , T., and Cifor, M., (2021, October). When Death Depends on Networked Information. Panel presented at AolR 2021: The 22nd Annual Conference of the Association of Internet Researchers. Virtual Event: AolR. Retrieved from http://spir.aoir.org. 
here and elsewhere. All the work that takes place here rests on the forceful appropriation of their lands by European settlers.

\section{Panel Abstract}

One of the founding stories of the United States centers on Patrick Henry's 1775 declaration "give me liberty, or give me death" on the floor of the Second Virginia Convention where war with Britain was being debated (Cohen, 1981). A similar sentiment is part of several national origin stories including the 1320 Declaration of Scottish Independence, which may have been an inspiration for Henry, and Greece's national motto of "Liberty or Death," which was the rallying cry in the 1820 Greek War of Independence. In each instance the suggestion is that independence will be achieved either through successful revolution or death. But in our modern networked cultures, what kind of independence can be found in death?

This panel takes up the AolR 2021 Independence theme by considering how our information and communication technologies are entangled with the end of human life, both at individual and community levels. Our case studies focus primarily on the United States and are deeply invested in considering practices that are evolving in the context of the Covid-19 pandemic, the ongoing HIVIAIDS pandemic, and the long epidemic of police killings of people of color in the U.S. In each of these long events, we are witnessing a myriad of efforts to collect mortality data and render it in ways that make sense of scales of loss. But questions about digital afterlives, networked and remixed loss, and proprietary control over digital remains complicates the foundational narratives of liberty through death and enrolls our dead in practices of nation formation even when those very lives were rendered expendable by the nation-state. At the same time, these practices are an important part of the problematic narrative that nothing dies on the internet, where deaths can circulate as undead memes and commodified data streams.

The papers on this panel examine the intersection of data management and speculative death (life insurance, mortality tables, pandemic statistics, counting the dead or potential dead) and death care management (personal digital archives, maintenance work, kinship ties, digital estate planning/mortuary rites, memorialization). As interdisciplinary scholars from Library and Information Science, Science and Technology Studies, and media history, we interrogate the historical, sociotechnical, and cultural aspects of sorting and caring for the dead through networked information. How are people, institutions, and infrastructures working to make sense of and account for the dead on both individual and collective scales? In what ways do histories of racialized and gendered surveillance and violence impact the treatment of the dead when it comes to both digital and physical remains? Major digital platforms and tech companies are increasingly at the center of memorialization and mourning practices, both building on and transforming the ways that these longer histories inform mortuary politics.

All four papers show how institutions and individuals are using digital media and networked information- from mortality data and barcodes affixed to coffins to social media memorials and crowdfunding platforms — to assess, track, memorialize, and 
otherwise manage the dead. We pay particularly close attention to the ways that race, gender, sexuality, immigration status, and citizenship affect how the dead are counted and remembered. We trace the history of technologies used to assess risk and manage mortality, comparing recent COVID-19 related developments to previous crises or pandemics and to longer histories of deathcare management as data management, including the history of the life insurance industry, mortality tables, and surveillance, from chattel slavery to contemporary predictive policing. In the 21st century the majority of these practices have transitioned to online and networked spaces, even as they continue to create social networks of information and ritual. Despite digital technologies being offered as a "solution" to the problem of death, our disparate case studies show how digital systems tend to reinforce existing structural inequalities, thereby troubling any sense that independence from violent social formations exists even in death.

\title{
References
}

Cohen, Charles (October 1981). "The 'Liberty or Death' Speech: A Note on Religion and Revolutionary Rhetoric". The William and Mary Quarterly. 38 (4): 702-717.

\section{Viral Memorialization: (Re)Making the Faces of AIDS and COVID-19 Marika Cifor University of Washington}

\begin{abstract}
"The fabric we were going to use for people who died is now going to be used for people, hopefully, to live," Gert McMullin shared (Shen-Berro, 2020). McMullin, an activist who has devoted the last three decades to memorializing people killed by the HIVIAIDS pandemic, was referencing 2020 efforts to sew leftover fabric from the AIDS Memorial Quilt into face masks for frontline workers amidst the COVID-19 pandemic. The Quilt, the most famous AIDS memorial, since 1985 has collected panels crafted by the dead's loved ones or fans, presenting names, lifespans and artifacts to memorialize individuals (Sturken, 1997: 186). The redeployment of materials from one pandemic to another highlights the intertwining of the COVID-19 and AIDS crises. Even as we live within the wreckage of their unrelenting devastation both pandemics are being similarly and actively memorialized. Digital pandemic memorials, including Instagram's The AIDS Memorial (@theaidsmemorial) and Faces of COVID (@FacesofCOVID) on Twitter, build on rethorical lineages of AIDS memorialization. Both also mobilize the viral affordances of digital platforms-instant content delivery, constant availability, hyper-interactivity (Cifor, 2021). In this paper, I examine how we make sense of pandemic deaths, physical and social, as multiple crises are unfolding, being weaponized, and enfolding our bodies. At this pandemic conjuncture how we memorialize viral losses online has urgent stakes.

Using André Brock's (2018) "Critical Technocultural Discourse Analysis" methodology, I undertake a close reading of @theaidsmemorial and @FacesofCOVID memorial and
\end{abstract}


the platform-driven accounts. Both have a tremendous following, interactivity, and activate platformed techno-social affordances. With each crowdsourced post these pandemic memorials are forming the faces of AIDS and COVID in America. Since April 2016, @theaidsmemorial has shared 7,000+ Instagram posts memorializing beloveds and public figures who have perished since 1981 in the AIDS epidemic with its more than 145,000 followers. Most of its subjects and followers are Americans. Its founder and moderator, Stuart, a Scottish Instagramer solicits, collects, edits, and shares posts of 1-10 images, alongside captions and metadata culled from email submissions. Similarly, @FacesofCOVID, founded by Alex Goldberg in March 2020, shares "stories of those lost to COVID per news reports, obits \& submissions." Most of its more than 145,000 followers and 5,000+ memorials are by and for Americans. In 240-character narratives, the account offers poignant snapshots contributed via a Google Form. @theaidsmemorial and @FacesofCOVID share an emphasis on memorializing individuals. Their visual repertoires revolve around portraits. Faces provide powerful messages, we read them for affect, identity, and relation and such images generate the most 'likes' and comments (Bakhshi et al., 2014). Faces matter too for stigmatized conditions that often rely on logics of individual responsibilization. To those who submit memorials each loss is more than a statistic or a dot in a data visualization.

Frequent comparisons are being made by scholars and in popular media between American COVID and AIDS pandemics as a means of sensemaking in the face of the uncertainty, fear, and precarity that are amplified by COVID-19. Yet, the intertwined digital memorialization of these pandemics on social media have yet to be examined. Pandemics exploit extant social fault lines, hierarchies, and inequalities. Tensions between memorializing individual lives deemed valuable and grievable (Butler, 2016), and the need for accountability and response amidst unending crises that disproportionately impact people subjected to social death need to be interrogated. Epidemic memorializations directly impact the life chances of the "viral underclass," Black and Brown people disproportionately harmed not just by organisms of biological viruses but by the societal structures that render them vulnerable to transmission, inadequate care, suffering, and death (Thrasher, 2020). While focused on the individual, the crowdsourced pictures and words these accounts share aggregate into vast, evergrowing catalogs of loss. They shape who is, and moreover who we can imagine to be living and dying now. As Douglas Crimp (2002) wrote in 1991, "In an [AIDS] epidemic that didn't have to happen, and whose continuing to this day to spread virtually unabated is the result of political neglect or outright mendacity, every death is unacceptable." Similarly, Goldberg said, "the responsibility I feel is to make these stories visceral and real because that is not only a more compassionate and empathetic way to deal with a crisis like this...it's also what forces us to ask hard questions about what was inevitable and what wasn't" (Cramer 2020). Memorialization on both accounts is an effort at accountability.

Pandemic memorials aspire to counter forgetting's violences, to remember those who have perished, recognize resistors, and offer lessons that catalyze different futures. Yet, pandemic commemorations also occupy a fraught temporal and material position. In America, the dying and the dead are often absented from daily life, demarcated into 
hospitals, hospices, funeral homes, and cemeteries (Gibbs et al., 2015: 256).

Commemoration too is often restricted to particular places and times.

@theaidsmemorial and @FacesofCOVID intervene, "repositioning the dead back within the flow of everyday life" (Ibid, 257). The dead through digital memorialization are reawakened becoming foundational to novel network formations, media practices, and affective relations (Papailias, 2016: 452). Both memorials build community around collective loss. It is likely these losses would not be otherwise publicly memorialized. Affect accumulates as the memorials circulate between networked users (Prybus, 2015: 240). The interactivity Instagram and Twitter afford memorialization is central to the accounts' promising affective potency, compelling outrage, grief, tenderness, sympathy, thereby engendering immediacy, and perhaps, action. Occurring in a society that fails to acknowledge and reckon with past or present trauma, and the role of the state, media, and different communities in exacerbating suffering and accelerating thousands of pandemic deaths these memorials are powerful forces in how we envision life after worlds as we knew them end.

\section{References}

Saeideh Bakhshi, David A. Shamma, and Eric Gilbert, "Faces engage us: Photos with faces attract more likes and comments on Instagram," Proceedings of the SIGCHI Conference on Human Factors in Computing Systems. Toronto, April, 2014: 965-974.

André Brock, "Critical technocultural discourse analysis," New Media \& Society 20, no. 3 (2018): 1012-1030.

Judith Butler, Frames of War: When Is Live Grievable? 3rd ed. New York: Verso, 2016.

Marika Cifor, "What is remembered lives: Time and the disruptive animacy of archiving AIDS on Instagram," Convergence 27, no. 2 (2021): 371-394.

Philissa Cramer, "Meet Alex Goldstein, who created the Faces of COVID Twitter account to help America face its grief, "Jewish Telegraphic Agency, October 13, 2020. https://www.jta.org/2020/10/13/united-states/the-man-behind-the-faces-of-covid-twitteraccount-wants-to-help-america-face-its-grief.

Douglas Crimp, "The Spectacle of Mourning" in Melancholia and Moralism: Essays on AIDS and Queer Politics (Cambridge: MIT Press, 2002), 201.

Martin Gibbs, James Meese, Michael Arnold, Bjorn Nansen, and Marcus Carter, "\#Funeral and Instagram: Death, social media, and platform vernacular," Information, Communication \& Society 18, no. 3(2015): 255-268.

Penelope Papailias, "Witnessing in the age of the database: Viral memorials, affective publics, and the assemblage of mourning," Memory Studies 9, no. 4, 2016: 437-454. 
Jennifer Prybus, "Accumulating Affect: Social networks and their archives of feelings." In: Networked Affect (Cambridge: MIT Press, 2015), 235-250.

Julian Shen-Berro, "Extra fabric from AIDS Memorial Quilt used for coronavirus masks," NBC, April 14, 2020. https://www.nbcnews.com/feature/nbc-out/extra-fabric-aidsmemorial-quilt-used-coronavirus-masks-n1183501

Marita Sturken, Tangled Memories: The Vietnam War, the AIDS Epidemic, and the Politics of Remembering. Berkeley: University of California Press, 1997.

Steven W. Thrasher, "An Uprising Comes from the Viral Underclass," Slate, June 12, 2020, https://slate.com/news-and-politics/2020/06/black-lives-matter-viralunderclass.html.

\section{Hustling After Death: COVID-19 and Platform Necropolitics}

Tamara Kneese

University of San Francisco, California

\section{Abstract}

Tithi Bhattacharya refers to social reproduction as "life-making activities," but extends that definition to the necropolitics of the COVID-19 crisis: "Capitalism privatizes life, but it also socializes death" (Jaffe, 2020). Essential workers who perform social reproduction - from nannies and meat processing plant workers to Instacart shoppers and Amazon delivery drivers - take on the risk of death; "essential" is racial capitalist code for "disposable." The ongoing pandemic spotlights not only long-term inequalities, but tensions within deathcare. On the one hand, digital deathcare emphasizes individual responsibility, asking people to prepare for their own deaths by employing data management tools. New models of algorithmic surveillance and attention encourage people to remain productive in the face of death as a macabre extension of what Tressie McMillan Cottom (2020) dubs the "hustle economy." On the other hand, digital death practices like crowdfunded funerals are fundamentally related to collective care and mutual aid, as evidenced by the role of crowdfunding platforms in social justice movements.

I draw on my long-term research on deathcare startups, including examples from my forthcoming book, Death Glitch: What Social Networks Leave Behind, to delineate how the pandemic is shaping deathcare practices in the United States. Internet researchers have described how social media platforms interface with mourning, memorialization, and mortuary rituals (Brubaker, Hayes, and Dourish, 2013; Gibbs et al., 2015; Marwick and Ellison, 2013). Meanwhile, the valuable data of the dead can be extracted by platforms, advertisers, and companies (Karppi, 2018; Leaver, 2013). At other times, remembrance of the dead through digital channels like hashtags is part of social justice 
activism, calling attention to people whose lives have been devalued by state violence and structural racism (Bonilla and Rosa, 2015; Benjamin, 2018). During the COVID-19 crisis, these earlier trends have taken on new significance. The pandemic lays bare the inequalities that leave some oppressed groups more likely to die than others, while also further intertwining sacred embodied care rituals with commercial platforms.

COVID-19 has intensified the role of death entrepreneurialism. When funerary rites shifted because of safety protocols, some deathcare workers like death doulas took on digital estate planning and other organizational tasks for grieving kin members (Cowles, 2020). The New York Times referred to the pandemic as a "Boom Time for Death Planning" (Miller, 2020). COVID has made young, white, and privileged people more aware of their own mortality. Death influencers are capitalizing on the pandemic and founding startups. As a testament to the growth of such companies, there are 70 startups in the Death and Company Slack channel, many of them founded by millennial women.

Deathcare management is an extension of neoliberal, ostensibly feminist self-care and a mark of personal responsibility. New death startups are partnering with insurance companies and employers, with the notion that workers will be more productive if they contemplate their own mortality. What I call "responsible death" is tied to larger risk management trends around corporate wellness, mindful labor, and workplace productivity (Gregg, 2018; Schüll 2016) and to much longer pernicious histories connecting the valuation of human life to metrics (Bouk 2015; Zelizer 1979; Wernimont 2019).

Despite startup companies' presentation of self-care as a way of managing mortality and mitigating illness and death, essential workers have no choice but to expose themselves to the virus. Gig workers, many of whom are immigrants, are treated as contractor "micro-entrepreneurs" and don't receive benefits. An Uber driver died of COVID-19 complications in 2020 precisely because he couldn't afford to stop working. Because he was classified as an independent contractor, Uber did not provide for his family after his death (Hussain 2020). When gig workers die at work, their loved ones often turn to GoFundMe as a de facto form of life insurance.

Long before the pandemic, many people crowdfunded for chemotherapy treatments and burials. In the US, many people don't have medical coverage- let alone life insurance policies - in the absence of a universal health care system. Neoliberal definitions of who is deserving of care inform which campaigns are successful and which fail (Berliner and Kenworthy, 2017). But for those who die without life insurance, crowdfunding campaigns can provide financial and emotional support to their loved ones.

Crowdfunding platforms, along with CashApp, Venmo, and PayPal, are instrumental to pandemic-related mutual aid efforts, which include paying off medical debt, burials, and mental health care for bereft families. In a feedback loop of attention, the more likes and shares that a campaign receives, the more a platform will promote it. GoFundMe dedicates a section of their website to funeral campaigns and highlights campaigns that 
are trending. This amplifies campaigns that are already in the news. The attention economy sometimes stalls out, privileging some lives and causes over others.

With GoFundMes becoming even more ubiquitous during the pandemic, such tensions and inequalities are heightened, particularly in a crisis that is disproportionately killing Black, Indigenous, Latinx, and disabled people. Deathcare, as a right, intersects with other labor organizing efforts and social movements connected to platform capitalism. Amid the pandemic, the Bay Area-based Gig Workers Collective and other worker-led groups are pushing for platforms to recognize their workers as employees, which also means caring for them and their families if they die on the job. Those on the frontline of the hustle economy are fighting for dignity in both life and in death.

\section{References}

Ruha Benjamin, "Black AfterLives Matter," Boston Review, July 16, 2018, http://bostonreview.net/race/ruha-benjamin-black-afterlives-matter.

Lauren Berliner and Nora Kenworthy, "Producing a Worthy IIlness: Personal Crowdfunding Amidst Financial Crisis," Social Science \& Medicine, 2017.

Yarimar Bonilla and Jonathan Rosa, "\#Ferguson: Digital protest, hashtag ethnography, and the racial politics of social media in the United States," American Ethnologist 42(1) 2015.

Dan Bouk, How Our Days Became Numbered. Chicago: University of Chicago Press, 2015.

Jed Brubaker, Gillian Hayes and Paul Dourish, "Beyond the Grave: Facebook as a site for the expansion of death and mourning," The Information Society 2013, 29, 3, 152.

Tressie McMillan Cottom, "The Hustle Economy," Dissent, Fall 2020, https://www.dissentmagazine.org/article/the-hustle-economy.

Charlotte Cowles, "How I Get It Done: Alua Arthur, Death Doula," The Cut, October 19, 2020, https://www.thecut.com/2020/10/how-i-get-it-done-alua-arthur-death-doula.html.

Martin Gibbs, James Meese, Michael Arnold, Bjorn Nansen, and Marcus Carter, "\#Funeral and Instagram: Death, social media, and platform vernacular," Information, Communication \& Society 18, no. 3(2015): 255-268.

Melissa Gregg, Counterproductive. Durham, NC: Duke University Press, 2018.

Suhauna Hussain, "This Driver Died of COVID: A Prop. 22 Story," Los Angeles Times, November 1, 2020, https://www.latimes.com/business/technology/story/2020-1101/prop-22-uber-driver-covid-19-death-benefits-workers-comp. 
Tero Karppi, Disconnect: Facebook's Affective Bonds. Minneapolis: University of Minnesota Press, 2018.

Sarah Jaffe, "Social Reproduction and the Pandemic, with Tithi Bhattacharya", Dissent, April 2, 2020, https://www.dissentmagazine.org/online articles/social-reproduction-andthe-pandemic-with-tithi-bhattacharya.

Tama Leaver, "The Social Media Contradiction: Data Mining and Digital Death," M/C Journal, 2013, 16(2).

Alice Marwick \& Nicole B. Ellison, "There Isn't Wifi in Heaven!" Negotiating Visibility on Facebook Memorial Pages," Journal of Broadcasting \& Electronic Media 2012 56(3): 378-400.

Jennifer Miller, "Boom Time for Death Planning." The New York Times, June 16, 22020, https://www.nytimes.com/2020/07/16/business/boom-time-for-deathplanning.html.

Natasha Dow Schüll, "Data for Life: Wearable Technology and the Design of Self-Care," BioSocieties 11, 2016.

Viviana Zelizer, Morals and Markets: The Development of Life Insurance in the United States. New York: Columbia University Press, 1979.

Jacqueline Wernimont, Numbered Lives: Life and Death in Quantum Media. Cambridge, MA: MIT Press.

\title{
Surveilling the Dead: Risk Management, Disaster Technologies, and the Digital Afterlife \\ Tonia Sutherland \\ University of Hawai'i at Mānoa
}

\begin{abstract}
In 2009 the Chicago school system implemented a program developed by consultants from the Massachusetts Institute of Technology (MIT) and the University of Chicago that would use predictive algorithms and archival records such as juvenile-detention reports, attendance records, and test scores to identify high-risk students and "assume, anticipate, predetermine, and foretell deadly violence (McKittrick, 2021: 104)." In other words, the Chicago public school system deployed an algorithm that would determine exactly which of their 400,000 students were "most at risk for being shot (Reel, 2014)." Predictive risk assessment and other risk management tools-such as the one developed for and used by the Chicago public schools-are increasingly common: they
\end{abstract}


are used to determine recidivism rates (Sutherland, 2019); for location-based proactive policing (cf. Geolitica [formerly PredPol]); and, increasingly, to augment disaster preparedness technologies.

With the addition of predictive risk assessment and other risk management tools, the disaster preparedness industry has become part of the United States's surveillance economy - one that has been shown to disproportionately impact Black lives (Browne, 2015). For example, after Hurricane Katrina-when hundreds of deceased Black people's bodies were separated from their caskets-the state of Louisiana passed legislation requiring that all coffins be given a unique identifier that could be linked to more robust records on the deceased. As an analog process, this method of tracking the dead had already produced mixed results—and limited success: death certificates tucked inside coffins were often destroyed by water and labels affixed to caskets were easily washed away. As a result, state officials began working to find a more permanent, data-based solution. Now, by using digital barcodes and attaching location tracking devices to coffins, state officials in Louisiana are working to quickly develop mobile applications to scan and trace what they colloquially call "runaways"-invoking with this language the brutality of slave patrols and likening the deceased to selfemancipated enslaved people, or "runaway slaves." By harnessing the power of simulations, decision trees, optimization, mapping, and other data-centric techniques, the technologies being developed and deployed under the auspices of risk management and disaster preparedness have created new modes and methods of surveilling Black bodies, even after death. And as the state of Louisiana begins to advertise itself as a "disaster laboratory (Robertson, 2016)," officials envision the state as a functional experiment in combatting storm surge, resettling imperiled communities-and keeping track of the dead.

Similarly, in the face of the global Covid-19 pandemic, funeral homes, cemeteries, crematoriums, and others in the deathcare industry have taken steps to maximize productivity using platforms specifically built for the cloud and delivered over the web to improve immediacy of access (primarily cloud-based software as a service [SaaS] platforms). Innovations in areas such as automatic obituaries using pre-populated forms, online inventories, and barcode systems have been particularly compelling as the death toll from Covid rises around the world. However, as Covid-19 mortality rates have proven to disproportionately impact Black, brown, and Indigenous communities in the United States (CDC, 2021), these technological innovations are also disproportionately being tested and deployed in communities of color. And while it is important to be able to track the hospitalized, the missing, and the dead during pandemics and in the aftermath of disaster, critical questions must be asked about the biases encoded into these technologies, and the conditions of possibility they create for surveillant harm to occur.

Using post-disaster efforts in the Louisiana Gulf Coast and deathcare technologies deployed during the Covid-19 pandemic as sites of inquiry, this paper considers weband cloud-based solutions to surveilling the dead under the auspices of risk management. Viewed through the lens of digital mortuary practices and hurricane 
disaster preparedness, the paper approaches disaster technologies as Simone Browne suggests: arguing that first and foremost, disaster technologies are human technologies where the ownership of and access to one's own body data must be understood as a right (Browne, 2010: 132). The paper addresses concerns about conflicting notions of "risk" and the uneven application of risk assessment and management tools through the lenses of race, records, and the surveillance of Black digital afterlives. The project first addresses the records that comprise the data that drives these technologies, problematizing both what comprises modern death and mortuary records and their digital afterlives. Next, the paper examines the nature of human bodies as records, framed by a discussion of the complex concerns raised by the deployment of risk management tools as disaster technologies in Black communities and other communities of color. The paper then speaks to concerns about agency and empowerment, making recommendation about how to responsibly handle a person's digital remains (here defined as the trails of data and metadata-both what people create and what is created for and about them-that are scattered across varying digital environments and that persist after death) at a time when deathcare industries have moved from analog to digital environments that render human bodies as data or as digitized code, increasingly usurping individuals' accounts of who they are and whether and where they belong.

\section{References}

Browne, Simone. Dark Matters: On the Surveillance of Blackness. Durham: Duke University Press, 2015.

Browne, Simone. "Digital Epidermalization: Race, Identity and Biometrics." Critical Sociology 36, no. 1 (2010): 131-150.

Centers for Disease Control and Prevention (CDC). "Health Equity Considerations and Racial and Ethnic Minority Groups." February 12, 2021.

https://www.cdc.gov/coronavirus/2019-ncov/community/health-equity/raceethnicity.html.

Geolitica. "Data-Driven Community Policing." https://geolitica.com/.

McKittrick, Katherine. Dear Science and Other Stories. (Durham: Duke University Press, 2021).

Reel, Monte. "Chronicle of a Death Foretold: Predicting Murder on Chicago's South Side." Harper's Magazine. March 2014. https://harpers.org/archive/2014/03/chronicle-ofa-death-foretold-2/.

Robertson, Campbell. “'We Built an App': Keeping Track of Louisiana's Flood-Tossed Tombs." The New York Times. September 18, 2016. https://www.nytimes.com/2016/09/19/us/we-built-an-app-keeping-track-of-louisianasflood-tossed-dead.html. 
Sutherland, Tonia. "The Carceral Archive: Documentary Records, Narrative Construction, and Predictive Risk Assessment." Journal of Cultural Analytics (2019). DOI: $10.22148 / 16.039$.

\title{
"To Make Death Data Faster": the History and Politics of the Effort to "Modernize and Automate" Mortality Statistics
}

Jacqueline Wernimont

Dartmouth

\begin{abstract}
In 2020 Judy Moulder, the director of the Office of Vital Records \& Health Statistics in Mississippi argued that efforts to modernize mortality data can only progress if agencies optimize the decidedly analog technology of human conversation (Moulder, 2020). Moulder's advice is likely to encounter the fierce headwinds of techno-solutionism that saturate the 25 year-old "International Collaborative Effort (ICE) on Automating Mortality Statistics" at the Centers for Disease Control (CDC) and within the National Vital Statistics System (NVSS) ("International Collaborative Effort on Automating Mortality Statistics," n.d.).
\end{abstract}

This project considers how the efforts to modernize the US death reporting system have been rhetorically positioned and materially pursued within both imagined and real shifts in American information and computing technologies. While this project focuses on U.S. efforts to automate death records, the first Mortality ICE includes participants from Australian, Brazilian, Canadian, French, British, Scottish, Spanish, and Swiss national agencies and subsequent proceedings had a wider transnational conversation (Proceedings vol 1, 1999).

For U.S. records produced before 2007, the history of automating death records is a history of multiple remediations from a range of textual materials. For records produced from 2008 onwards, this may also a story of remediation but one more fully encapsulated in digital media. Given the patchwork of implementation of Electronic Death Registry Systems and provider use, the system currently has to accept paper, telecom, and digital transmission of information in order to ultimately transform the entire whole into standardized digital information. According to a 2020 audit, only one state, Indiana was able to meet the goal of $90 \%$ digital registration of death events. As Moulder suggests, transforming these various data depends on several levels of human interaction. Because mortality reports are federated - states process death records according to state laws and then sell that information to the federal surveillance and records system - the effort to get all 50 states and the 12 territories and jurisdictions to simultaneously adopt the same digital technologies and workflows is a complex network and systems challenge. Perhaps it should come as no surprise then that the mortality automation project is 25 years and counting in the making. Indeed, the techno- 
utopianism underlying the current effort at modernization has been at the heart of our federated system since the end of the $19^{\text {th }}$ century.

Indeed, the first efforts to modernize and automate the death records system at the federal level began in 1968 with the development of a software system known as ACME (for Automated Classification of Medical Entities). "ACME was designed with three goals: 1) to use software that embodies a set of explicit rules and relationships and could be modified and updated to select the underlying cause of death more consistently than could be done by manual coders, 2 ) to simplify data entry and thereby reduce the cost of training medical coders and nosologists, and 3) to produce multiple as well as underlying cause-of-death data" (Proceedings vol 1,1999). ACME's success was only partial given that the instructions to operate the software were at least as complex as manual death coding and as a result did not yield the hoped-for cost and time savings. Subsequent development of an additional three systems, TRANSAX, MICAR and SuperMICAR has enhanced our ability to understand the multiple factors leading to human death and have standardized the information in line with WHO guidelines and international efforts, but has not achieved the goal of simplifying the process or reducing cost.

Initially the Mortality ICE effort involved little discussion of networked information; while international standardization and digital processing were both goals for the participants in the first meeting in the 1996, the internet is only mentioned six times in the 218-page proceedings and where it does appear it is mostly as a repository for coding training materials for use by doctors. This changes dramatically by the time the group meets for the second meeting just three years later in 1999 (Proceedings vol. 2, ) when Edward Sondik, Director of the National Center for Health Statistics, extolled the "astonishing... power of computer technology and the Internet" (Proceedings vol 2., 27). By that point the participants from more than 25 countries world-wide were hoping to have real time or, at the least, daily mortality data collected through national information networks that all depended on either public internet or secure governmental intranet networks. It is also at the 1999 meeting that we begin to see discussion of distributed work and remote reporting appear as central themes in the effort to make death data faster.

By the time of the 2003 meeting of the Mortality ICE the desire to automate and standardize mortality data has expanded into creating a digital "life record" that could be accessed for several different governmental purposes from marriage and divorce registration to birth and death tracking (Proceedings vol 3, p 83). Along with this change is a shift to born digital documents and web-served databases of information. There is also an increased effort to mandate online mortality reporting, providing exemptions only in "limited cases" where "there may not be any Internet service" and the local "funeral director is also the local butcher" (Proceedings vol 3, 83). Embedded within the discussions of technical affordances and costs are a remarkable set of assumptions about how Americans die and who is involved in the processes of certifying death and preparing a body for final services. Additionally, the increasing efforts to automate and 
network mortality and life information seem to iteratively edit out exactly the kinds of human conversation and intervention that are foregrounded in Moulder's 2020 essay.

Understanding the histories and the politics of "making death data faster" are crucial to understanding how mortality information is imagined to flow in and across nations and the roles such information plays in national and transnational governance and public health efforts. Moulder's essay frames my analysis of the work of the Mortuality ICE precisely because it seems to deviate from the kind of disembodied technology driven information networks that come to dominate the Mortality ICE discussions.

One insight of this project is that competing interests, especially those articulated by congress around national security and social service fraud have taken over half of the work load of the already overburdened local vital registrars. As a consequence, registrars have been unable both in terms of human capacity and funding to serve both their service function to a nation of workers who must document their identity and public health official who depend on mortality tracking to understand regular disease spread and emerging viral threats like COVID 19. Given that Moudler's call for listening and communication between people, it is worth considering how "regular" death registration might differ from that during a crisis and how internet and communication technologies might interfere with, rather than aid, our understanding of mortality data in crises, like the COVID-19 pandemic. Additionally, given the central role of networked information in the U.S government's approach to mortality data, we might well ask how the digital and connected technologies and process are shaping governmental and personal action. Thomas Laqueur has argued that our "dead make social worlds" and this project helps us to understand how internet and computing technologies have participated in this making of social worlds.

\section{References}

- "International Collaborative Effort (ICE) on Automating Mortality Statistics" https://www.cdc.gov/nchs/nvss/ice automation.htm accessed 4/14/2021.

- Proceedings of the International Collaborative Effort on Automating Mortality Statistics vol 1 https://www.cdc.gov/nchs/data/misc/ice99 1.pdf accessed 4/14/2021

- Proceedings of the International Collaborative Effort on Automating Mortality Statistics vol 2, 2001. https://www.cdc.gov/nchs/data/misc/ice01 acc.pdf

- Proceedings of the International Collaborative Effort on Automating Mortality Statistics vol 3, 2006. https://www.cdc.gov/nchs/data/misc/ice06 3.pdf

Laqueur, Thomas. The Work of the Dead: A Cultural History of Mortal Remains (New Haven: Princeton University Press, 2015).

Moulder, Judy. "To Make Death Data Faster, Just Listen" Public Health and Surveillance, n.d. Centers for Disease Control and Prevention, Deputy Director for 
Public Health Science and Surveillance. https://www.cdc.gov/surveillance/blogsstories/Make-Death-Data-Faster.html accessed 4/14/2021. 